\title{
Modeling and Experimental Validation of A Transient Direct Expansion Heat Pump
}

\author{
Clément Rousseau*, Jean-Louis Comlan Fannou, Louis Lamarche and Stanislaw Kajl \\ École de technologie supérieure, Montréal, Canada
}

*1100 Notre-Dame Street West, Montréal, Quebec H3C 1K3, 514 209-1761;

\begin{abstract}
Geothermal heat pump technology is currently one of the most interesting technologies used to heat buildings. There are two designs used in the industry: geothermal heat pump using a secondary ground loop and Direct Expansion (DX) ground source heat pump. The latter is less used, possibly because less research has been carried out for the design of this kind of heat pump. In this paper, a transient model using the Comsol Multiphysic of a DX ground heat pump is presented in heating mode with R22, and a comparison with experimental results is presented with a 24 -hour test. It is shown that the model was adequately validated by our experiment with only a maximum difference of $15 \%$. Following this validation, a parametric analysis was realised on the geometry of the borehole. This study concluded that to have the best heat extraction of the ground, the pipes shank spacing need to be important without increasing the borehole diameter.
\end{abstract}

Keywords: Direct Expansion geothermal heat pump, Modeling, R22

Article History: Received January 16 ${ }^{\text {th }}$ 2017; Received in revised form May 28 ${ }^{\text {th }} 2017$; Accepted June 6 ${ }^{\text {th }} 2017$; Available online

How to Cite This Article: Rousseau, C., Fannou, J.L.C., Lamarche, L. and Kajl, S. (2017) Modeling and Experimental Validation of a Transient Direct Expansion Heat Pump. International Journal of Renewable Energy Develeopment, 6(2), 145-155.

https://doi.org/10.14710/ijred.6.2.145-155

\section{Introduction}

The last decade has seen a jump in interest in the Geothermal Heat Pump (GHP). This may be explained by the fact that this technology can provide heating and cooling for a building at very low cost. There are two designs used in the industry, namely, the Geothermal Heat Pump using a secondary ground loop and the Direct Expansion (DX) ground source heat pump. Both operate on the simple vapour compression refrigeration cycle (Beauchamp et al. 2013), with the main difference between them being that with the DX geothermal heat pump (Fig. 1), the ground heat exchanger is part of the refrigeration cycle. The energy and operational performances of the system are thus directly related to the working fluid behavior, the refrigerant, in relation with the ground heat transfer.

A review of the literature reveals the presence of several publications on geothermal secondary loop systems (Belzile, et al. 2016, Capozza, et al. 2012, Esen and Inalli 2009, Ruiz-Calvo and Montagud 2014, Self, et al. 2013), but a lack of scientific research and publications on direct expansion geothermal heat pump systems. One of the first studies of the DX heat pump was conducted by Smith (1956), who studied a geothermal DX horizontal heat pump and compared it to a secondary loop heat system. He proved that the size of the exchanger can be reduced, but also that the heat rejection or heat absorption needs to be controlled according to changes in ground temperature. One problem he encountered was in controlling the oil in the ground exchanger. Following this study, many other research endeavours also arrived at the same conclusion (Freund and Whitlow 1959, Goulburn and Fearon 1978, 1983).

More recently, a few works have been published on DX heat pumps. Wang et al. (2009)conducted an experimental study of a DX heat pump with the refrigerant $\mathrm{R} 134 \mathrm{a}$ in heating mode. Their system consisted of three vertical $30 \mathrm{~m}$ deep boreholes examined over a period of 20 days in the winter. According to the results, on average, COPhp and COPsys were 3.55 and 2.28, respectively, and the average heating capacity obtained was $6.43 \mathrm{~kW}$. They noted the problem of maldistribution of refrigerant flow between the boreholes. Wang et al. (2013)conducted an experimental study on a DX heat pump in heating mode, consisting of four vertical $20 \mathrm{~m}$ wells, for which a copper coil system was developed to facilitate oil return.

\footnotetext{
* Corresponding author: clement.rousseau.2@ens.etsmtl.ca
} 
Citation: Rousseau, C., Fannou, J.L.C., Lamarche, L. and Kajl, S. (2017) Modeling and Experimental Validation of a Transient Direct Expansion Heat Pump. International Journal of Renewable Energy Development, 6(2),145-155, https://doi.org/10.14710/ijred.6.2.145-155

$\mathrm{P}$ a g e | 146

\begin{tabular}{|c|c|c|c|c|c|}
\hline $\mathrm{A}$ & Internal section of the pipe & $\left(\mathrm{m}^{2}\right)$ & $\operatorname{Re}$ & Reynolds Number & \\
\hline$c_{p}$ & Specific heat & (J/kg.K) & $\mathrm{R}$ & Rayon & $(\mathrm{m})$ \\
\hline $\mathrm{Cc}$ & Cylinder clearance & $(\mathrm{m})$ & $\mathrm{T}$ & Temperature & $(\mathrm{K})$ \\
\hline $\mathrm{D}_{\mathrm{e}}$ & External diameter of the pipe & (m) & $\mathrm{t}$ & Time & (s) \\
\hline $\mathrm{D}_{\mathrm{i}}$ & Internal diameter of the pipe & $(\mathrm{m})$ & $\mathrm{W}_{\mathrm{c}}$ & Work of the compressor & $(\mathrm{kW})$ \\
\hline $\mathrm{D}_{\mathrm{b}}$ & Extern diameter of the borehole & $(\mathrm{m})$ & $\mathrm{x}$ & Quality of Vapour & $(\mathrm{m})$ \\
\hline $\mathrm{f}$ & Friction factor & & $\mathrm{z}$ & Depth & \\
\hline$f_{r}$ & Compressor pulsation frequency & $(\mathrm{Hz})$ & & & \\
\hline G & Mass flux & $\left(\mathrm{kg} / \mathrm{s} . \mathrm{m}^{2}\right)$ & & Greek & \\
\hline $\mathrm{g}$ & Gravitational acceleration & $\left(\mathrm{m} / \mathrm{s}^{2}\right)$ & & & \\
\hline \multirow[t]{2}{*}{$\mathrm{H}_{\mathrm{r}}$} & Heat transfer coefficient & $\left(\mathrm{W} / \mathrm{m}^{2} . \mathrm{K}\right)$ & $\rho$ & Density & $\left(\mathrm{kg} / \mathrm{m}^{3}\right)$ \\
\hline & between the pipe and the flow & & $\mu$ & Dynamic viscosity & (Pa.s) \\
\hline $\mathrm{H}_{\mathrm{s}}$ & $\begin{array}{l}\text { Heat transfer coefficient, } \\
\text { between the pipe and the grout }\end{array}$ & $\left(\mathrm{W} / \mathrm{m}^{2} . \mathrm{K}\right)$ & $\theta$ & $\begin{array}{l}\text { Angle of the pipe compared } \\
\text { to the horizontal }\end{array}$ & \\
\hline \multirow[t]{2}{*}{$\mathrm{H}_{\mathrm{p}}$} & Heat transfer coefficient, & $\left(\mathrm{W} / \mathrm{m}^{2} . \mathrm{K}\right)$ & $\sigma$ & Surface tension & $(\mathrm{N} / \mathrm{m})$ \\
\hline & between the grout and the ground & & $\tau$ & Shear stress & $(\mathrm{Pa})$ \\
\hline $\mathrm{Hc}$ & Heat transfer coefficient, & $\left(\mathrm{W} / \mathrm{m}^{2} . \mathrm{K}\right)$ & & C ulo & \\
\hline $\mathrm{h}$ & Specific enthalpy & $(\mathrm{J} / \mathrm{kg})$ & & suoscripts & \\
\hline $\mathrm{h}_{\mathrm{fg}}$ & Enthalpy of Phase Changes & $(\mathrm{J} / \mathrm{kg})$ & $\mathrm{c}$ & Grout & \\
\hline $\mathrm{k}$ & Thermal conductivity & $(\mathrm{W} / \mathrm{m} . \mathrm{K})$ & $\mathrm{f}$ & Liquid phase & \\
\hline $\mathrm{L}$ & Length of the pipe & (m) & $\mathrm{g}$ & Gas phase & \\
\hline$\dot{m}$ & Mass flow rate & $(\mathrm{kg} / \mathrm{s})$ & $\mathrm{m}$ & Mixture of liquid and gas of & \\
\hline $\mathrm{n}$ & Polytropic exponent & & & $\mathrm{R} 22$ & \\
\hline $\mathrm{Q}_{\mathrm{h}}$ & Heat flux of the condenser & $(\mathrm{kW})$ & $\mathrm{p}$ & Pipe & \\
\hline $\mathrm{Q}_{1}$ & Heat flux of the evaporator & $(\mathrm{kW})$ & $\mathrm{s}$ & Ground & \\
\hline$v$ & Speed of the R22 & $(\mathrm{m} / \mathrm{s})$ & $\mathrm{i}$ & At the entry of the & \\
\hline $\mathrm{V}_{\text {comp }}$ & Clearance volume & $\left(\mathrm{m}^{3}\right)$ & & evaporator & \\
\hline $\mathrm{P}$ & Pressure & $(\mathrm{Pa})$ & & & \\
\hline $\operatorname{Pr}$ & Prandtl Number & & & & \\
\hline
\end{tabular}

Austin et al. (2011) present a very interesting parametric study of a vertical DX heat pump with $\mathrm{CO} 2$, especially the impact of the number and the length of the loop on the COP. They improved the COP by $18 \%$ and the heat flux of the condenser by $17 \%$. Fannou et al. (2014) analyzed an experiment with three vertical 30 $\mathrm{m}$ deep boreholes in heating mode, like Wang et al., but with R22. They concluded that a dimensioning effort should be made to minimize the pressure drop in the evaporator in order to find a compromise between low pressure drop, oil return and refrigerant charge. In 2011, Halozan (Halozan 2011) presented a study on the commercialization of ground source heat pumps and the barriers facing the technology, in which he highlighted the lack of a design method as one of the major problems facing DX technology. In 2010, a report by the U.S. Department of Energy (2010) showed that 87,717 geothermal heat pump with secondary loops were installed in 2009 in the USA, compared to only 759 DX units.

In 2014, Eslami-Nejad et al. (2014) developed a quasi-steady-state model of a vertical borehole with $\mathrm{CO}_{2}$. This model can be used in a geothermal heat pump application. Much like in the classical heat pump market, the use of $\mathrm{CO} 2$ in the geothermal heat pump is probably going to increase in the coming years.

This review show a big gap for this technology, there is not a transient model of a direct expansion geothermal heat pump in the literature. Even if a lot of classical transient models of heat pumps can be found (Underwood 2016, Vargas and Parise 1995, White, et al. 2002), they can't be used with a direct expansion geothermal application. The modeling of this heat transfer in the ground is more complex and difficult to take account for this type of model. A new model needs to be developed.

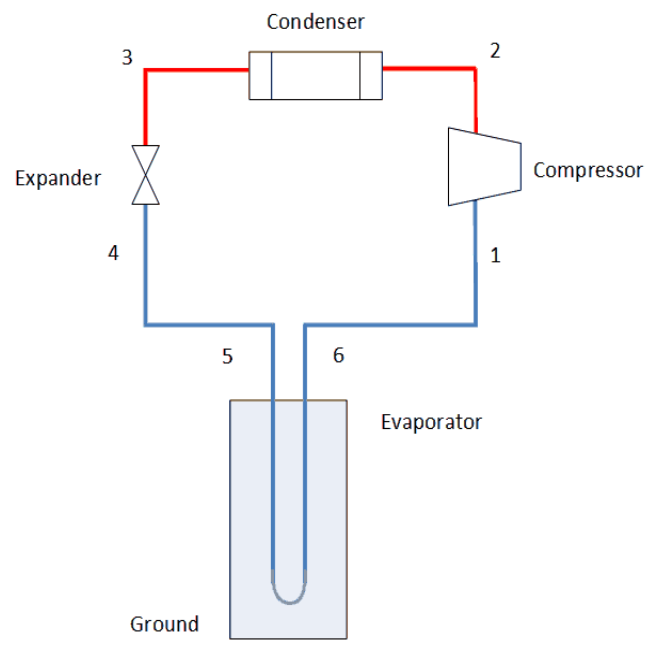

Fig. 1 Direct expansion heat pump

The proposed modeling and analysis of this DX heat pump therefore aims to fill this gap and to help improve this technology. Modeling and analyzing a direct expansion geothermal heat pump begins with the modeling of different components: ground heat exchanger, compressor, thermostatic expansion valve, reversing valve, pipe, and water-refrigerant exchanger, and the coupling of these components to form a closed loop corresponding to the heat pump.

A previous studied by Rousseau et al. (2015) already looked at the analysis and modeling of the 
ground heat exchanger in evaporator mode. In this study, all components of the heat pump are fully coupled in order to model the whole DX system in an unsteady analysis. The simulation is done with R22 as refrigerant since it was the one used in our experimental set-up but can be used with other refrigerants as well.

\section{Theory}

In this study, the model is divided into four components (see Fig. 1):

- The compressor, between points 1-2

- $\quad$ The condenser, between points 2-3

- The expander, between points 3-4

- $\quad$ The evaporator, between points 5-6

For each exchanger, the governing continuity, momentum and energy and heat exchange equations were solved using Comsol Multiphysics 4.2. The compressor and expander were solved with steady state equations. For the condenser and evaporator, transient equations were used to take into account the impact of the ground and the control of the superheat.

\subsection{Compressor}

The pressure at the entry of the compressor was calculated with the classical expression:

$$
\mathrm{P}_{1}=\frac{\mathrm{P}_{2}}{\left(\left(1-\frac{\dot{\mathrm{m}}_{1}}{\rho_{1} \cdot \mathrm{V}_{\text {comp }} \cdot \mathrm{f}_{\mathrm{r}}}\right) \cdot \frac{1}{\mathrm{Cc}}+1\right)^{\mathrm{n}}}
$$

The work of the compressor was calculated with:

$$
\begin{aligned}
& \dot{\mathrm{W}}_{\mathrm{c}}=\dot{\mathrm{m}}_{2} \frac{\mathrm{n}}{\mathrm{n}-1} \cdot \frac{\mathrm{P}_{1}}{\rho_{1}} \cdot\left[\left(\frac{\mathrm{P}_{2}}{\mathrm{P}_{1}}\right)^{\frac{\mathrm{n}-1}{\mathrm{n}}}-1\right] \\
& \mathrm{h}_{2}=\frac{\dot{\mathrm{W}}_{\mathrm{c}}}{\dot{\mathrm{m}}_{2}}+\mathrm{h}_{1}
\end{aligned}
$$

The following are all the properties of the compressor used in this article, they can be found with the documentation of the compressor (Table 1). The rotation speed of the compressor, $f_{r}$, can be changed in the experiment and the model. The rest of the property is fixed for the experiment. For more information, see Ndiaye and Bernier (2010).

Table 1

Parameters of the compressor

\begin{tabular}{cc}
\hline Variables & Values \\
\hline $\mathrm{V}_{\text {comp }}$ & $67.011 .10^{-6}$ \\
$\mathrm{f}_{\mathrm{r}}$ & 60 \\
$\mathrm{Cc}$ & 0.14 \\
$\mathrm{n}$ & 1.114 \\
\hline
\end{tabular}

\subsection{Condenser}

The condenser in this study is a heat exchanger with two coaxial tubes with an inner tube that is used to heat water and an outer tube with the R22 flow.

For each flow, R22 and water, the governing continuity, momentum and energy equations are solved.

$$
\begin{aligned}
& \frac{\partial \rho_{\mathrm{m}} \mathrm{A}}{\partial \mathrm{t}}+\frac{\partial \dot{\mathrm{m}}}{\partial \mathrm{z}}=0 \\
& \frac{\partial \dot{\mathrm{m}}}{\partial \mathrm{t}}+\frac{\partial \dot{\mathrm{m}} \mathrm{v}}{\partial \mathrm{z}}+\frac{\partial \mathrm{P}_{\mathrm{m}} \mathrm{A}}{\partial \mathrm{z}}=-\tau_{\mathrm{w}} \mathrm{Pr} \\
& \frac{\partial \rho_{\mathrm{m}} \mathrm{Ah}}{\partial \mathrm{t}}+\frac{\partial \dot{\mathrm{m}} \mathrm{h}_{\mathrm{m}}}{\partial \mathrm{z}}=\frac{\partial \mathrm{P}_{\mathrm{m}} \mathrm{A}}{\partial \mathrm{t}}+\mathrm{q}_{\mathrm{c}}{ }^{\prime}+\mathrm{v} \frac{\partial \mathrm{P}_{\mathrm{m}} \mathrm{A}}{\partial \mathrm{z}}
\end{aligned}
$$

With

$$
\begin{aligned}
& \mathrm{q}_{\mathrm{c}}{ }^{\prime}=\mathrm{H}_{\mathrm{r}} \pi \mathrm{D}_{\mathrm{i}}\left(\mathrm{T}_{\mathrm{p}}-\mathrm{T}\right) \\
& \tau_{\mathrm{w}}=\frac{\mathrm{fm} \mathrm{v}}{8}
\end{aligned}
$$

The friction factor was calculated with the Garimella correlation (Garimella and Christensen 1995a) for the condenser.

Hc in Eq. (7) is calculated with:

- Garimella's correlation (Garimella and Christensen 1995b), for one-phase flow

- Koyama's correlation (Koyama, et al. 1990), for two-phase flow

For more information about the model and the validation of the condenser see (Fannou, et al. 2012).

\subsection{Expander}

The expander is a major component in this system, and serves two purposes: decrease the pressure between the two exchangers and control the superheat at the entry of the compressor.

The expander is considered an isenthalpic.

$$
\mathrm{h}_{4}=\mathrm{h}_{3}
$$

In this study, the classical representation of the expander is used:

$$
\dot{\mathrm{m}}_{3}=\sqrt{\frac{\mathrm{P}_{3}-\mathrm{P}_{4}}{\mathrm{C}_{\mathrm{X}}}}
$$

$\mathrm{Cx}$ represent a valve coefficient which is minimum when the valve is fully opened $\left(\mathrm{X}_{\mathrm{s}}=1\right)$ and maximum when it is closed $(\mathrm{Xs}=0)$ 
Citation: Rousseau, C., Fannou, J.L.C., Lamarche, L. and Kajl, S. (2017) Modeling and Experimental Validation of a Transient Direct Expansion Heat Pump. International Journal of Renewable Energy Development, 6(2),145-155, https://doi.org/10.14710/ijred.6.2.145-155

P a g e | 148

$$
C_{X}=\left(V_{h}-V_{b}\right) \cdot\left(1-X_{s}\right)+V b
$$

It is assumed that the opening of the valve $(\mathrm{Xs})$ varies linearly with the superheat

$$
\mathrm{X}_{\mathrm{s}}=\left[\left(\mathrm{T}_{1}-\mathrm{T}_{\mathrm{sat} \mathrm{P} 1}\right)-\mathrm{T}_{\text {superheat }}\right] \cdot \mathrm{a}_{\mathrm{s}}+\mathrm{b}_{\mathrm{s}}
$$

Here, the superheat, $\mathrm{T}_{\text {superheat, }}$ setpoint is fixed at $9.5 \mathrm{~K}$, as it was the case in the experiment, with the two constants as and bs, being 0.1 and 10, respectively. These constants were found by calibrating the model to the experimental data. See section 3.0 for more information about the experimental heat pump use in this study.
The constant $\mathrm{Vb}$ is calculated using the initial pressure drop of the expander, and Vh can be found using the maximum pressure drop that the expander is capable of achieving using the documentation or experiment.

In this study:

$$
\begin{aligned}
& \mathrm{Vh}=7.5 \mathrm{e} 9 \quad \mathrm{~Pa} . \mathrm{s}^{2} / \mathrm{kg}^{2} \\
& \mathrm{Vb}=2.23 \mathrm{e} 9 \mathrm{~Pa} . \mathrm{s}^{2} / \mathrm{kg}^{2}
\end{aligned}
$$

In this model, it is not the mass flow rate in the expander which is calculated, but rather, the pressure at the entry of the expander, $\mathrm{P}_{3}$.

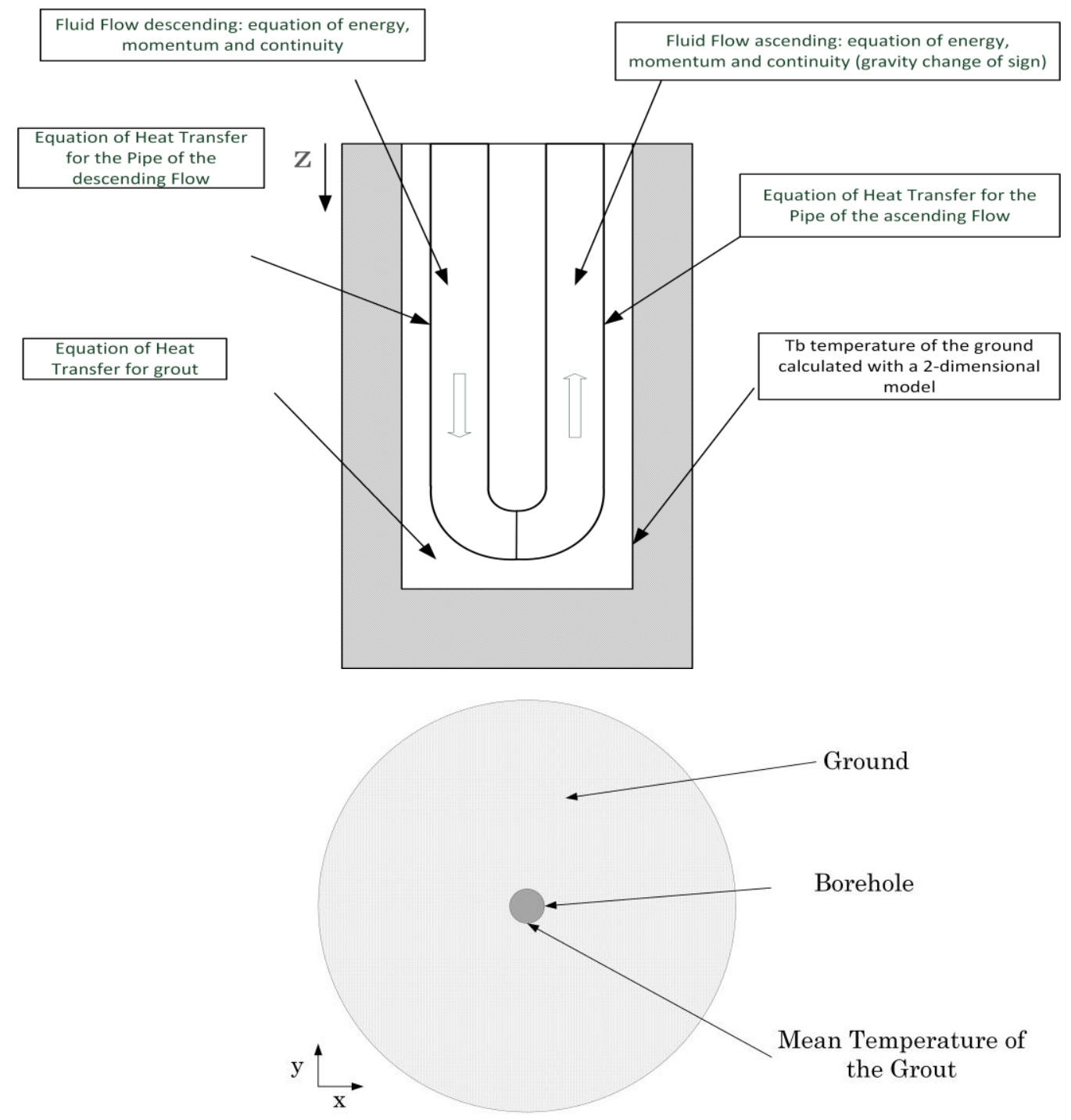

Fig. 2 Direct expansion heat pump

\subsection{Evaporator}

The evaporator is composed of 6 different elements (see Figure 2):

- The R22 flow rate descending in the borehole
- $\quad$ The R22 flow rate ascending in the borehole

- $\quad$ The copper pipe where the R22 is descending

- The copper pipe where the R22 is ascending

- The grout surrounding the pipes

- The ground around the borehole 
In this study, the governing continuity, momentum and energy equations, as well as the equations relating to the heat exchange between the flow and the pipe, the pipe and the grout, and finally, the grout and the ground, are solved in a $1 \mathrm{D}$ model.

$$
\begin{aligned}
& \frac{\partial \rho_{\mathrm{m}} \mathrm{A}}{\partial \mathrm{t}}+\frac{\partial \dot{\mathrm{m}}}{\partial \mathrm{z}}=0 \\
& \frac{\partial \dot{\mathrm{m}}}{\partial \mathrm{t}}+\frac{\partial \dot{\mathrm{m} v}}{\partial \mathrm{z}}+\frac{\partial \mathrm{P}_{\mathrm{m}} \mathrm{A}}{\partial \mathrm{z}}=-\tau_{\mathrm{w}} \mathrm{Pr}-\rho_{\mathrm{m}} \mathrm{Ag} \sin \theta \\
& \frac{\partial \rho_{\mathrm{m}} \mathrm{Ah}}{\partial \mathrm{t}}+\frac{\partial \dot{\mathrm{m}} \mathrm{h}_{\mathrm{m}}}{\partial \mathrm{z}}=\frac{\partial \mathrm{P}_{\mathrm{m}} \mathrm{A}}{\partial \mathrm{t}}+\mathrm{q}_{\mathrm{r}}{ }^{\prime}+\mathrm{v} \frac{\partial \mathrm{P}_{\mathrm{m}} \mathrm{A}}{\partial \mathrm{z}} \\
& \mathrm{q}_{\mathrm{r}}{ }^{\prime}=\mathrm{H}_{\mathrm{r}} \pi \mathrm{D}_{\mathrm{i}}\left(\mathrm{T}_{\mathrm{p}}-\mathrm{T}\right)
\end{aligned}
$$

Hr in Eq. (15) is calculated using Gnielinski (Gnielinski 1975) for one-phase flow and Chen (Chen 1966) correlation for two-phase flow.

The temperature of the pipe and the grout is solved with the following equations (17-20):

$$
\begin{aligned}
& \rho_{\mathrm{p}} \cdot \mathrm{A}_{\mathrm{p}} \cdot \mathrm{Cp}_{\mathrm{p}} \frac{\mathrm{dT} \mathrm{p}}{\mathrm{dt}}=-\mathrm{q}_{\mathrm{r}}{ }^{\prime}+\mathrm{q}_{\mathrm{p}}{ }^{\prime}+\mathrm{k}_{\mathrm{p}} \cdot \mathrm{A}_{\mathrm{p}} \cdot \frac{\partial^{2} \mathrm{~T}_{\mathrm{p}}}{\partial \mathrm{z}^{2}} \\
& \mathrm{q}_{\mathrm{p}}{ }^{\prime}=\mathrm{H}_{\mathrm{p}} \cdot \pi \cdot \mathrm{D}_{\mathrm{e}} \cdot\left(\mathrm{T}_{\mathrm{c}}-\mathrm{T}_{\mathrm{p}}\right) \\
& \rho_{\mathrm{c}} \cdot \mathrm{A}_{\mathrm{c}} \cdot \mathrm{Cp}_{\mathrm{c}} \cdot \frac{\mathrm{dT} \mathrm{c}}{\mathrm{dt}}=-\mathrm{q}_{\mathrm{p} 1}{ }^{\prime}-\mathrm{q}_{\mathrm{p} 2}{ }^{\prime}+\mathrm{q}_{\mathrm{s}}{ }^{\prime}+\mathrm{k}_{\mathrm{c}} \cdot \mathrm{A}_{\mathrm{c}} \\
& \cdot \frac{\partial^{2} \mathrm{~T}_{\mathrm{c}}}{\partial \mathrm{z}^{2}} \\
& \mathrm{q}_{\mathrm{s}}{ }^{\prime}=\mathrm{H}_{\mathrm{s}} \cdot \pi \cdot \mathrm{D}_{\mathrm{b}} \cdot\left(\mathrm{T}_{\mathrm{s}_{\text {mean }}}-\mathrm{T}_{\mathrm{c}}\right)
\end{aligned}
$$

With $\mathrm{q}_{\mathrm{p} 1}$ and $\mathrm{q}_{\mathrm{p} 2}$ ' the flux of the descending and ascending flow. $\mathrm{H}_{\mathrm{s}}$ and $\mathrm{H}_{\mathrm{p}}$ was determined using the Kennelly's delta-star transformation of the circuit of Hellstrom (Hellström 1991).

The thermal response of the ground is solved in a $2 \mathrm{D}$ model do be able to represent the interaction of different boreholes in a future work.

$$
\rho_{\mathrm{s}} \cdot \mathrm{Cp}_{\mathrm{s}} \cdot \frac{\mathrm{dT}_{\mathrm{s}}}{\mathrm{dt}}=\mathrm{k}_{\mathrm{s}} \cdot \frac{\partial^{2} \mathrm{~T}_{\mathrm{s}}}{\partial \mathrm{x}^{2}}+\mathrm{k}_{\mathrm{s}} \cdot \frac{\partial^{2} \mathrm{~T}_{\mathrm{s}}}{\partial \mathrm{y}^{2}}
$$

with at the contact between the ground and the borehole:

$$
n \cdot\left(-k_{s} \cdot \nabla T_{s}\right)=\mathrm{H}_{s} \cdot\left(T_{c_{\text {mean }}}-T_{s}\right)
$$

More details on the evaporator model is described in Rousseau et al. (Rousseau, et al. 2015).

The only difference in this study is that for the coupling, the pressure is imposed at the exit of the exchanger with the Eq. (23), and not at the entry of the evaporator. This change is necessary for the coupling between the models.

As stated in the previous study (Rousseau, et al. 2015), there is a pressure drop between the borehole and the entry of the compressor. The pressure at the exit of the borehole was increased by $100 \mathrm{kPa}$ to consider this pressure drop. The enthalpy at the entry of the compressor was considered to be the same as at the exit of the evaporator, and that there was no heat loss between the two components.

$$
\begin{aligned}
& \mathrm{P}_{1}=\mathrm{P}_{6}-100 \mathrm{e} 3 \\
& \mathrm{~h}_{1}=\mathrm{h}_{6}
\end{aligned}
$$

In the experiment, only one loop was active, but a part of the flow passed into the two over one loop. The mass flow rate in the evaporator is set at $80 \%$ of the mass flow rate total in order to take this loss into account. This percentage was found by calibrating the model to the experimental data in the first study.

$$
\begin{aligned}
& \dot{\mathrm{m}}_{4}=\dot{\mathrm{m}}_{3} \\
& \dot{\mathrm{m}}_{5}=0.8 \cdot \dot{\mathrm{m}}_{4} \\
& \dot{\mathrm{m}}_{1}=\frac{\dot{\mathrm{m}}_{6}}{0.8} \\
& \dot{\mathrm{m}}_{2}=\dot{\mathrm{m}}_{1}
\end{aligned}
$$

The heat loss between the expander and the compressor needs to be calculated, and the following experiment was used to calculate the correction:

$$
\mathrm{h}_{5}=\mathrm{h}_{4}-9000
$$

\section{Model}

The model is compared to the experimental heat pump located at the CTT in Montreal, (see Figure 3). The experimental setup used in this unit is a model DXWG-45 by Maritime Geothermal Company with a nominal capacity of $10 \mathrm{~kW}$ in cooling mode and 17.6 in heating mode with:

- A compressor piston, type (Tecumseh AVA5538EXN)

- A heat exchanger with coaxial water-refrigerant pipes (Turbotec BTSSC-60)

- Three expansion valves TXV heating (model Danfoss TUBE 068U2162)

- An accumulator to protect the compressor In this study, only one borehole (so one expansion valves) is activated. 
Citation: Rousseau, C., Fannou, J.L.C., Lamarche, L. and Kajl, S. (2017) Modeling and Experimental Validation of a Transient Direct Expansion Heat Pump. International Journal of Renewable Energy Development, 6(2),145-155, https://doi.org/10.14710/ijred.6.2.145-155

P a g e | 150

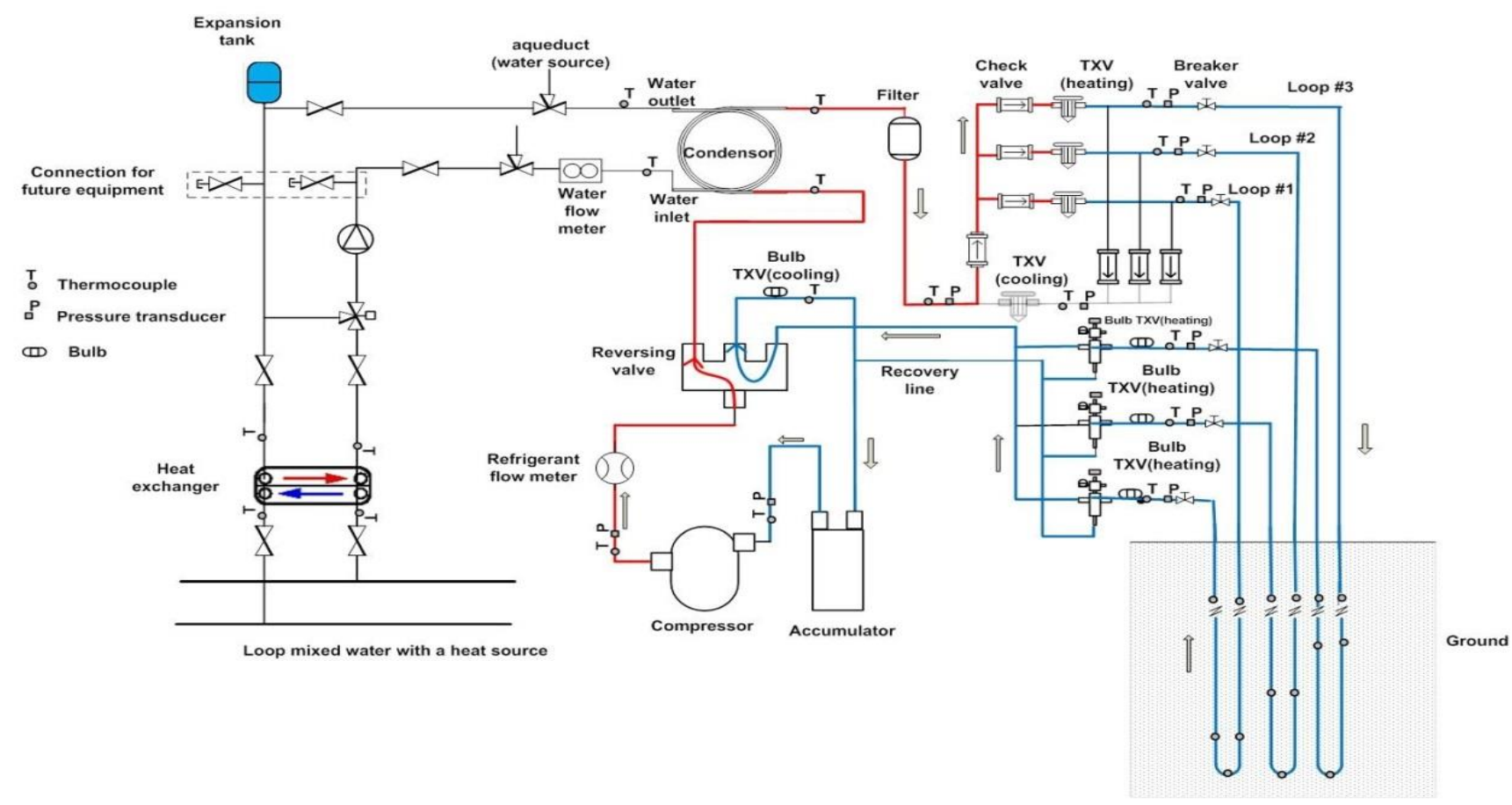

Fig. 3 Schematic of experimental device in heating mode

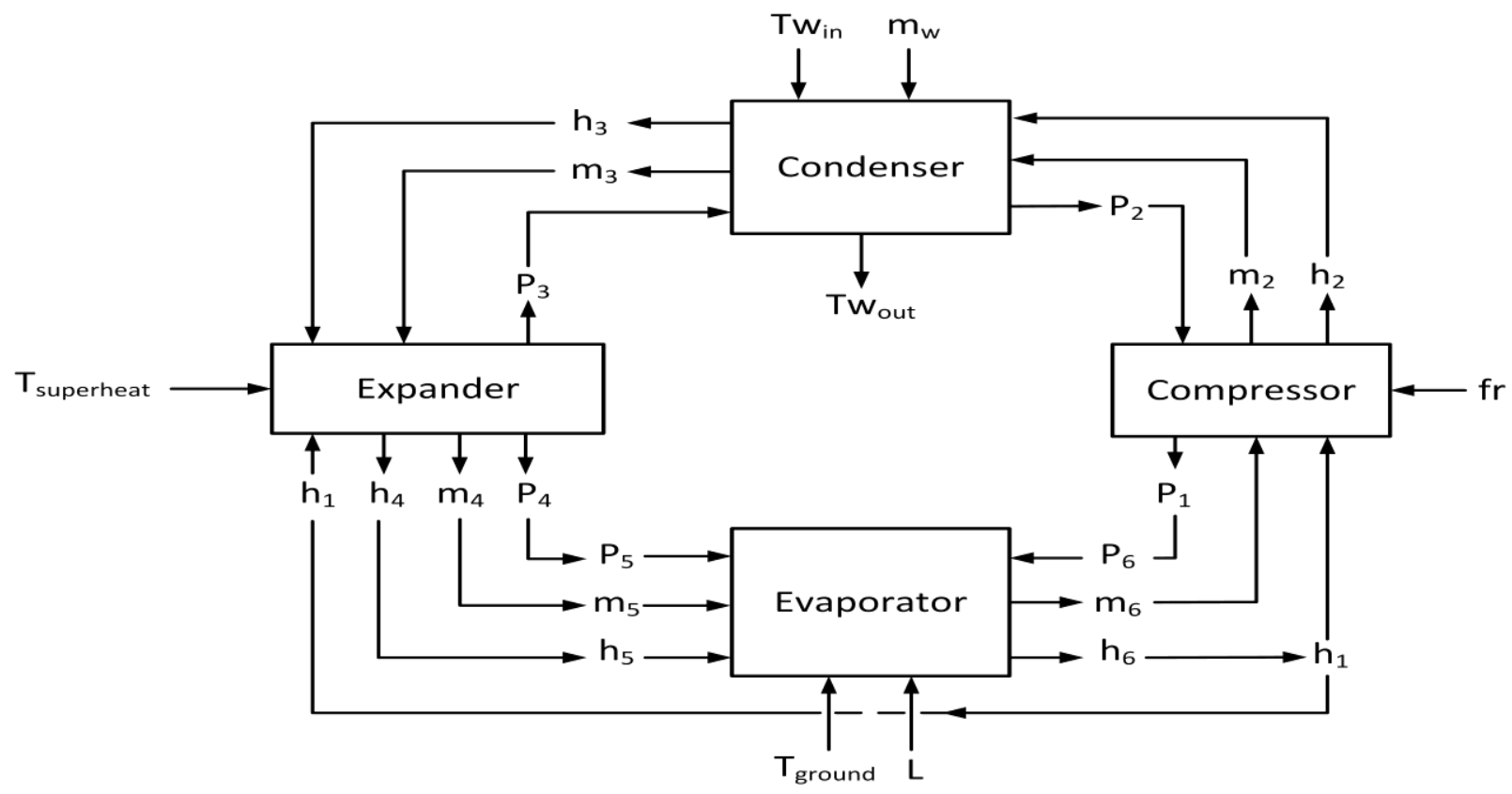

Fig. 4 Entry and exit of all the models

To help the convergence of the simulation, the components were not coupled at the beginning. After few minutes of the simulation, the full coupling was activated. The whole coupling strategy is illustrated in Fig. 4. The initial conditions for each component were taken from the experiment. Initially, each component works independently (see Figure 4).
In this study, many coupling methods for assembling the component models were tested. The final choice was to impose the pressure at the entry of the compressor (Eq. 1) and compute the flow rate using the expander law (Eq. 10).

The valve controls the superheat at point 1 . For example, when the superheat decreases: 
- The parameter $\mathrm{X}_{\mathrm{s}}$ of the expander decreases, and so $\mathrm{C}_{\mathrm{X}}$ increases (Eqs. (11) and (12))

- Then $\mathrm{P}_{3}$ increases

- Then $\dot{\mathrm{m}}_{3}$ and $\dot{\mathrm{m}}_{4}$ decrease

- That affects the pressure at the entry and exit of the compressor, $\mathrm{P}_{2}$ increases and $\mathrm{P}_{1}$ decreases

- And with $\mathrm{P}_{1}$ and $\dot{\mathrm{m}}_{4}$ decreasing,

- Finally, the superheat increases

Table 2

Initial Condition

\begin{tabular}{cc}
\hline Variables & Values \\
\hline $\mathrm{P}_{1}(\mathrm{~Pa})$ & $360.10^{3}$ \\
$\mathrm{P}_{2}(\mathrm{~Pa})$ & $1350.10^{3}$ \\
$\dot{\mathrm{m}}_{2}(\mathrm{~kg} / \mathrm{s})$ & 0.017 \\
$\dot{\mathrm{m}}_{5}(\mathrm{~kg} / \mathrm{s})$ & 0.0212 \\
$\mathrm{~h}_{2}(\mathrm{~J} / \mathrm{kg} \cdot \mathrm{K})$ & $4.59 .10^{5}$ \\
$\mathrm{~h}_{4}(\mathrm{~J} / \mathrm{kg} \cdot \mathrm{K})$ & $2.317 .10^{5}$ \\
\hline
\end{tabular}

The parameters of the experiment, and for the model, are presented in Table 3.

Table 3

Parameters of the model

\begin{tabular}{lc}
\hline Variables & Values \\
\hline Le1, length of descending flow $(\mathrm{m})$ & 40 \\
Le2, length of ascending flow $(\mathrm{m})$ & 40 \\
Di1, internal diameter of descending flow $(\mathrm{mm})$ & 7.9 \\
Di2, internal diameter of ascending flow $(\mathrm{mm})$ & 11.07 \\
Di1, external diameter of descending flow $(\mathrm{mm})$ & 9.5 \\
Di2, external diameter of ascending flow $(\mathrm{mm})$ & 12.7 \\
Ts, initial temperature $(\mathrm{K})$ & 287 \\
Db, diameter of the borehole $(\mathrm{m})$ & 0.076 \\
$\mathrm{D}$ Distance between pipes $(\mathrm{m})$ & 0.02 \\
$\mathrm{k}_{\mathrm{p}}(\mathrm{W} / \mathrm{m} . \mathrm{K})$ & 401 \\
$\mathrm{Cp}$ ( $\mathrm{J} / \mathrm{kg} \cdot \mathrm{K})$ & 385 \\
$\rho_{\mathrm{p}}\left(\mathrm{kg} / \mathrm{m}^{3}\right)$ & 1000 \\
$\mathrm{k}_{\text {grout }}(\mathrm{W} / \mathrm{m} \cdot \mathrm{K})$ & 1.4 \\
$\mathrm{Cp}$ grout $(\mathrm{J} / \mathrm{kg} \cdot \mathrm{K})$ & 800 \\
$\rho_{\text {grout }}\left(\mathrm{kg} / \mathrm{m}^{3}\right)$ & 2300 \\
$\mathrm{k}_{\text {ground }}(\mathrm{W} / \mathrm{m} . \mathrm{K})$ & 2.8 \\
$\mathrm{Cp}$ ground $(\mathrm{J} / \mathrm{kg} \cdot \mathrm{K})$ & 600 \\
$\rho_{\text {ground }}\left(\mathrm{kg} / \mathrm{m}^{3}\right)$ & 2000 \\
$\theta$ & $\pi$ \\
Entry temperature of water in the condenser & 301.15 \\
Length of the condenser $(\mathrm{m})$ & 6.3 \\
Le1, length of descending flow $(\mathrm{m})$ & 40 \\
\hline
\end{tabular}

The parameters for the compressor and the valve are given in sections 2.1 and 2.3 .

\section{Result and Discussion}

\subsection{Validation}

To validate the model, a comparison was carried out between the model and the experiment in a 24 -hour test. The comparison was based on the pressure, the enthalpy and the flow rate in the condenser and in the evaporator, between the experiment and the model.

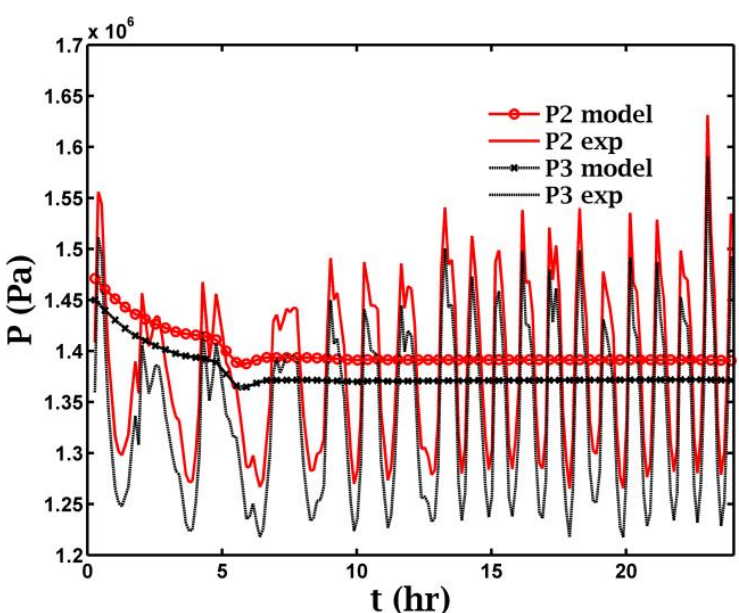

Fig. 5 Entry and exit of all the models

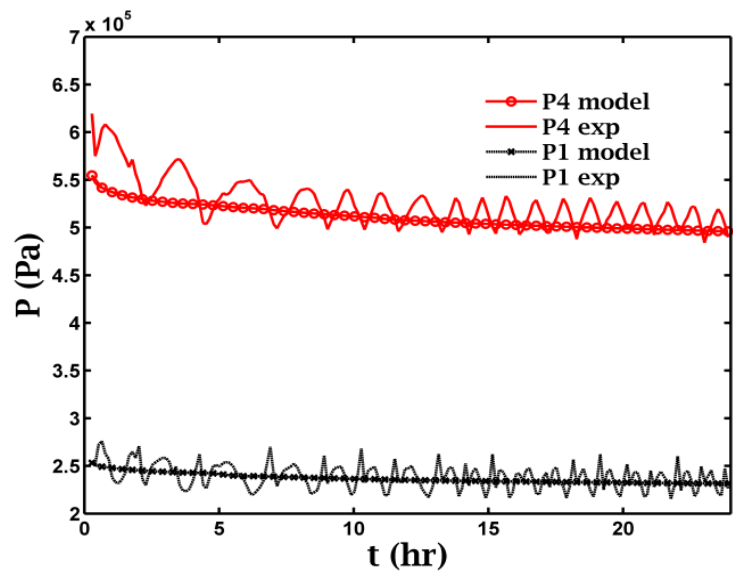

Fig. 6 Pressure in the evaporator

Figure 5 and 6 show that the evolution of the pressure in the model and in the experiment is very similar. For the condenser, the pressure at the entry and exit in the model is similar to what it is seen in the experiment. The same conclusion can be drawn for the evaporator, where the decrease in pressure at the exit of the expander (point 4) is very similar what it is observed experimentally.

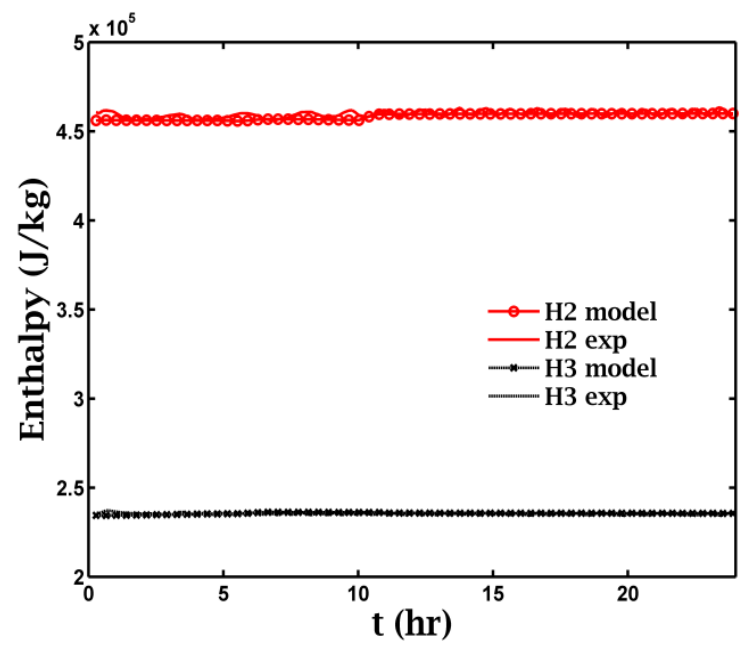

Fig. 7 Enthalpy in the condenser 
Citation: Rousseau, C., Fannou, J.L.C., Lamarche, L. and Kajl, S. (2017) Modeling and Experimental Validation of a Transient Direct Expansion Heat Pump. International Journal of Renewable Energy Development, 6(2),145-155, https://doi.org/10.14710/ijred.6.2.145-155

P a g e | 152

Figure 7 and 8 show the evaluation of the enthalpy in the condenser and in the evaporator, respectively. Initially, there is a small difference between the model and the experiment, but after 5 hours, the difference disappears. That is when the superheat reaches $9.5{ }^{\circ} \mathrm{C}$, and the expander starts regulating the system

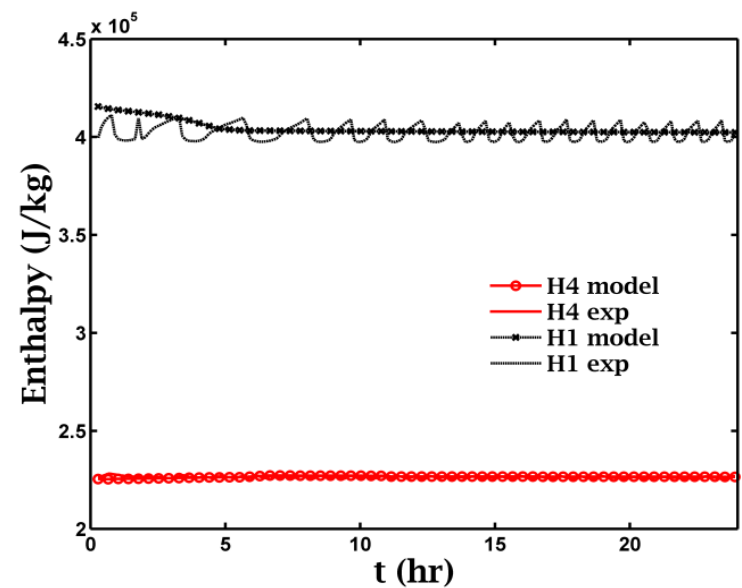

Fig. 8 Enthalpy in the evaporator

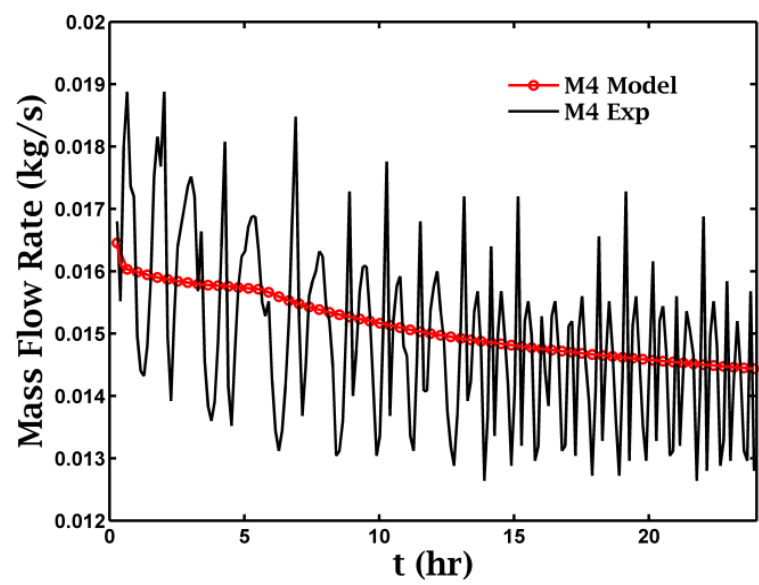

Fig. 9 Mass flow rate at the entry of the evaporator

Figure 9 shows the change in the mass flow rate in the evaporator. Initially, the mass flow rate does not change significantly in the model, but at 5 hours, the superheat is equal to the set point value of the valve. At that point, the valve begins to close, reducing the mass flow rate in the evaporator .

Figure 10 presents the difference between the heat flux of the condenser between the experimental and the model. The same evolution is reproduce by the model. The heat flux is here much smaller than the nominal capacity $(17.6 \mathrm{~kW})$ in the experiment and the model. That is due to the fact that only one borehole is used. As reported in (Beauchamp 2011), the use of one borehole can reduce by $38 \%$ the heat rejected at the condenser.

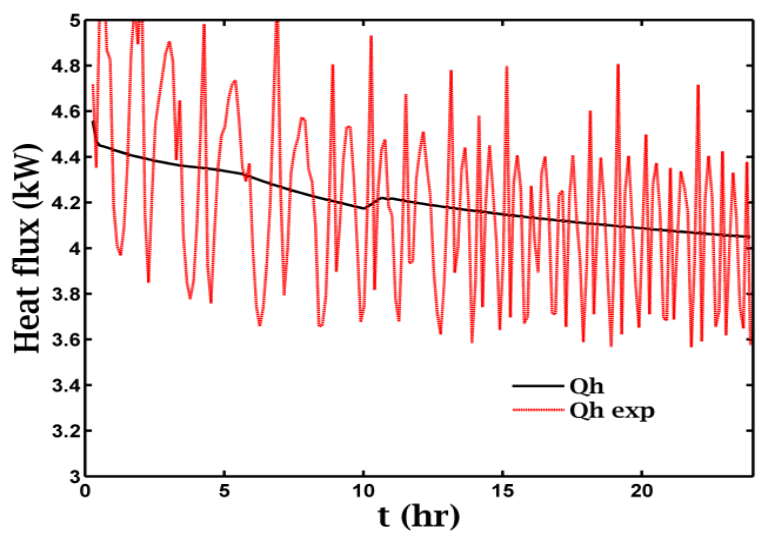

Fig. 10 Heat flux in the condenser

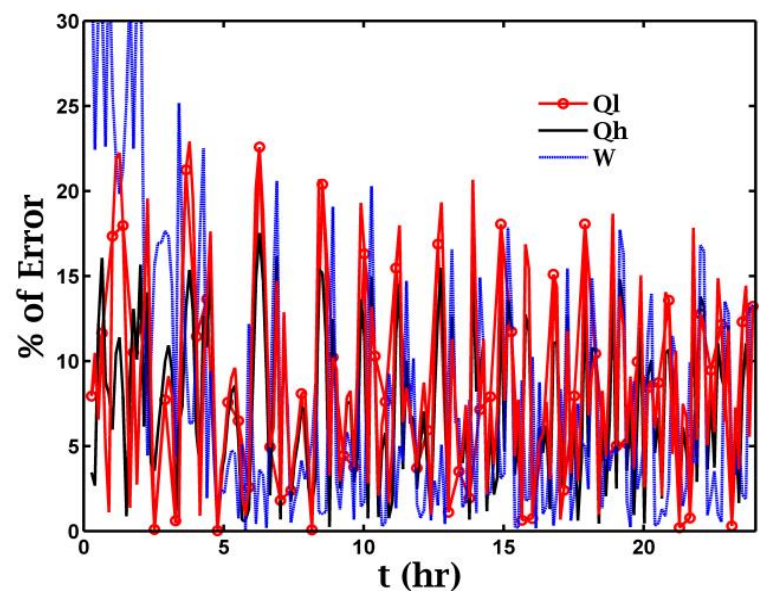

Fig. 11 Difference in \% between $\mathrm{Ql}, \mathrm{Qh}$ and Wcomp in the experiment and model

In Figure 11 the percentage difference between $\mathrm{Q}_{\mathrm{h}}$, $\mathrm{Q}_{1}$ and $\mathrm{W}_{\text {comp }}$ in the experiment versus the model is compared. This difference is small, after 5 hours. At the beginning, the choice of the initial conditions is very important, and the differences are larger.

\subsection{Long-term testing}

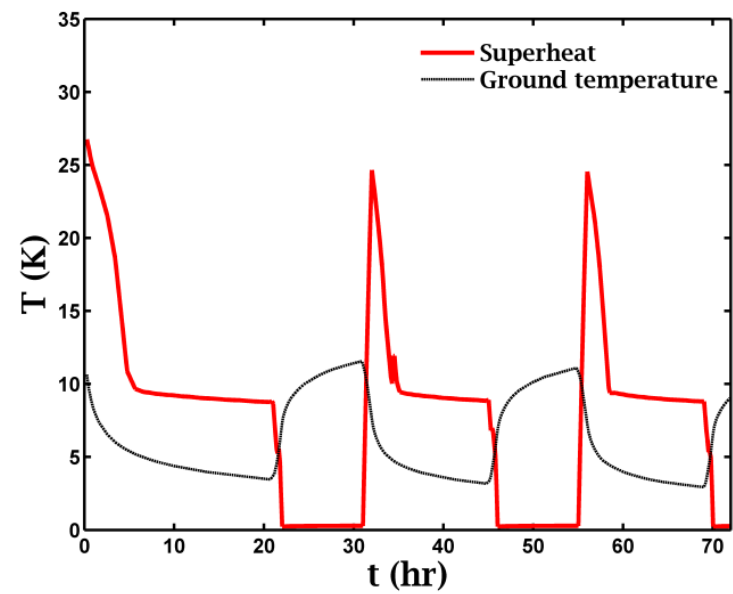

Fig. 12 Superheat and ground temperature 


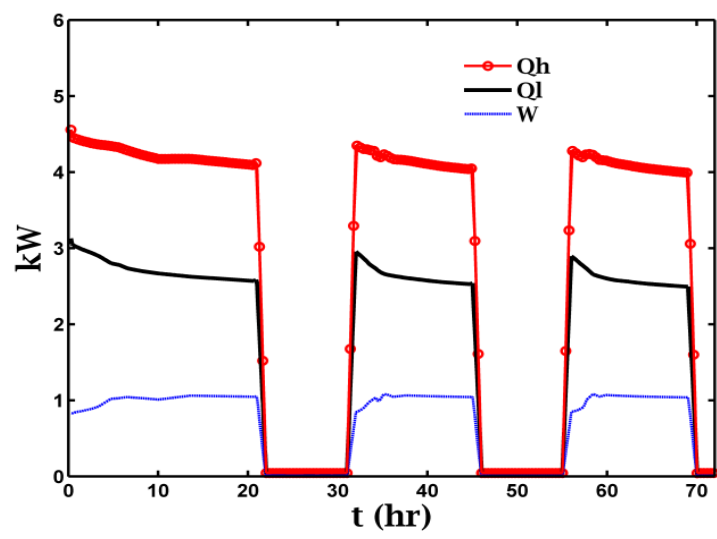

Fig. 13 Heat flux and work of the compressor

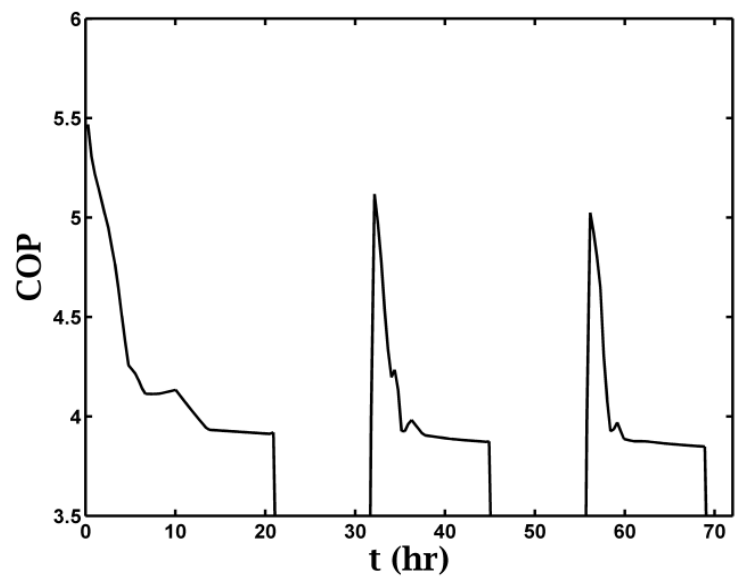

Fig. $14 \mathrm{COP}$ of the heat pump

The model was used to determine the response of a long-time running with an on/off cycle, which is active between $8 \mathrm{AM}$ and $10 \mathrm{PM}$ and deactivated between 10 PM and 8 AM. The total duration was three days. Unfortunately, no comparison with the experiment can be done, because no experiment test of this type was produced.

Figure 12 to Figure 14 show that, as expected, the system can work for extended periods. The ground temperature increases when the system stops, allowing the system to begin the next phase with a good performance level. Figure 14 shows that the performance slowly decreases with each cycle. This is because the ground temperature at the beginning of each cycle has decreased, and the pause is not long enough for the ground to recover. In classical operation, the steps are going to be much smaller depending on the charge of the system.

\subsection{Temporal variation}

In order to evaluate the dynamic behavior of the model, a change in the superheat set-point value and in the water entry temperature in the condenser is studied in this section.

Figure 15 shows the change of the superheat setpoint value from $9.5^{\circ} \mathrm{C}$ to $12^{\circ} \mathrm{C}$ and from $9.5^{\circ} \mathrm{C}$ to $7{ }^{\circ} \mathrm{C}$. In the case of a decrease in the superheat set-point, the system works very well. First the superheat decreases rapidly; this can be explained by the fact that the valve will open at $100 \%$. After that, the superheat will decrease and, after reaching the set-point, the expander will close to stabilize the superheat.

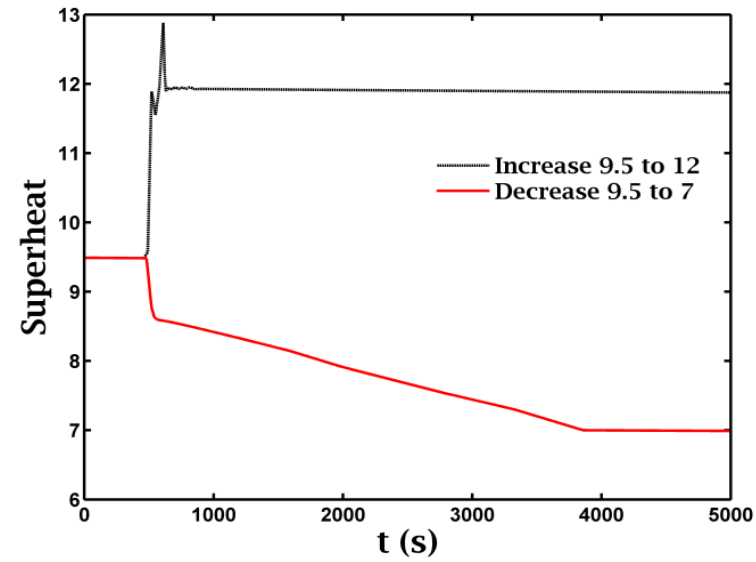

Fig. 15 Change of the superheat set

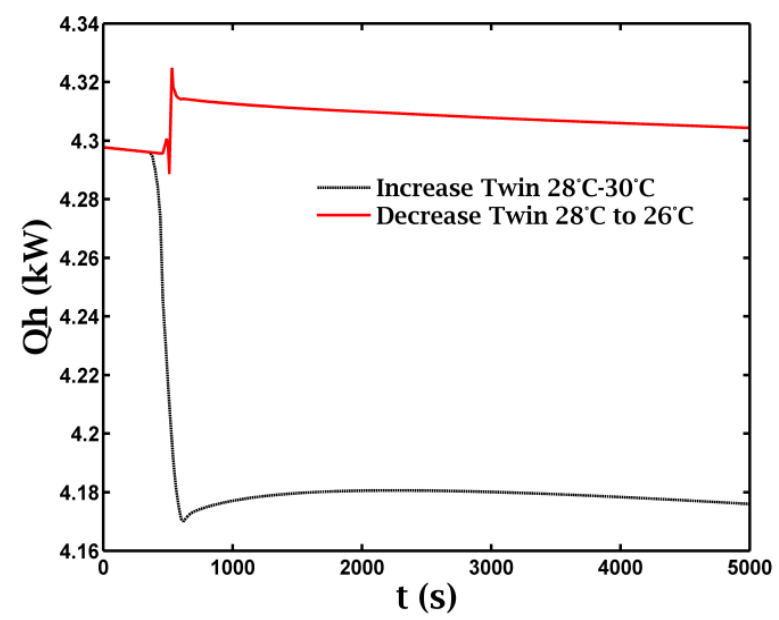

Fig. 16 Impact of the water entry temperature on $\mathrm{Qh}$

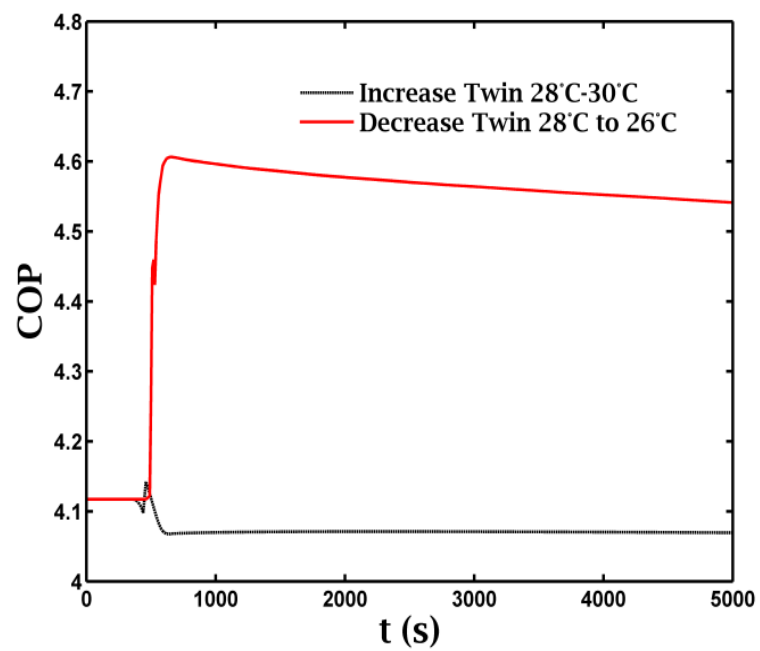

Fig. 17 Impact of the water entry temperature on the COP 
Citation: Rousseau, C., Fannou, J.L.C., Lamarche, L. and Kajl, S. (2017) Modeling and Experimental Validation of a Transient Direct Expansion Heat Pump. International Journal of Renewable Energy Development, 6(2),145-155, https://doi.org/10.14710/ijred.6.2.145-155

$\mathrm{P}$ a g e | 154

In the case of an increase in the superheat setpoint, a lot of small perturbations is observed at the beginning. This is due to the rapid closing of the valve and its fast impact on the system. After 50 seconds the superheat stabilizes. Modeling the dynamic of the valve would probably help to have a better behavior.

Figure 16 shows the impact of the water entry temperature on the heat exchange in the condenser. As reported in Beauchamp (2011), a small increase in the water temperature is going to affect the heat rejected in the condenser. An interesting observation that is shown in this test, is that a two degree increase of $\mathrm{T}_{\text {win }}$ reduce $\mathrm{Q}_{\mathrm{h}}$ by $3 \%$, but a decrease of two degree only increases $\mathrm{Q}_{\mathrm{h}}$ by $0.3 \%$. If we look the variation of the COP, Figure 17 , the decrease in $\mathrm{T}_{\text {win }}$ is going to have a greater impact, an increase of $12 \%$ compare to the effect of decreasing the temperature. These two tests show that this transient model can be used to model the small unsteady changes.

\subsection{Parametric study}

A complete a parametric study of the model was also studied by changing the geometry of the ground heat exchanger in a 24 hours test (Figure 18):

- The length of the borehole, Le

- The diameter of the borehole, $\mathrm{D}_{\mathrm{b}}$

- The distance between the pipe and the center of the borehole, $\mathrm{D}_{\mathrm{cb}}$

First of all, the impact of the length of the borehole was studied. Table 4 shows that, increasing the length, increases the performance of the system for $24 \mathrm{~h}$. For the $50 \mathrm{~m}$ length, the COP are higher compared to the other ones. The reason is that the expander does no modulation because the superheat is higher than the setpoint. This explains why the work of the compressor is lower. With a longer simulation time, the COP will be lower and closer to the other ones. It's interesting to see that the difference on the COP between the $30 \mathrm{~m}$ and 40 $\mathrm{m}$ lengths is small but the difference in capacity $\mathrm{Qh}$ is bigger.

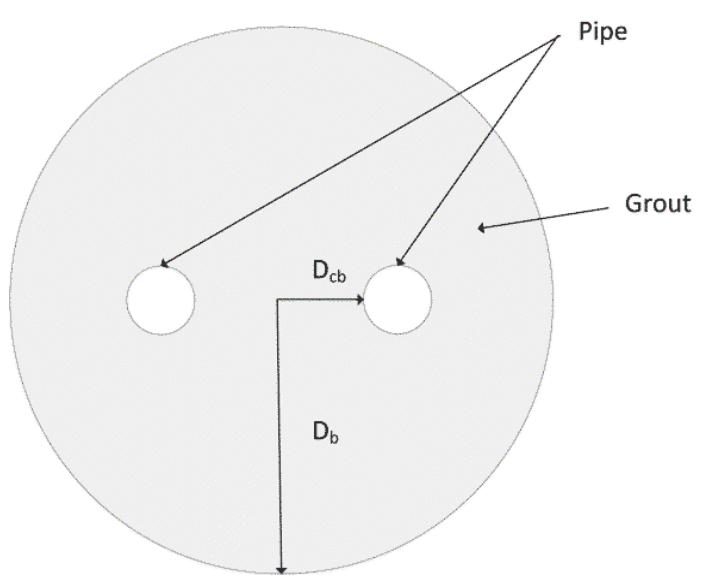

Fig. 18 Parametric study of the ground exchanger
Table 4

Parametric study: length of the borehole

\begin{tabular}{ccccc} 
Le (m) & $\mathbf{Q}_{\mathbf{h}}(\mathbf{k W})$ & $\mathbf{Q}_{\mathbf{1}}(\mathbf{k W})$ & $\mathbf{W}_{\mathbf{c}}(\mathbf{k W})$ & $\mathbf{C O P}$ \\
& & & & \\
\hline 30 & 3,521 & 2,176 & 0,94 & 3,746 \\
40 & 4,049 & 2,538 & 1,039 & 3,897 \\
50 & 4,275 & 2,834 & 0,906 & 4,719 \\
\hline
\end{tabular}

Table 5 shows the impact of the borehole diameter keeping the borehole length to $40 \mathrm{~m}$. Increasing the diameter reduces the heat extraction rate. However, the impact on the COP is small.

Table 5

Parametric study: diameter of the borehole

\begin{tabular}{ccccc}
$\mathbf{D b}(\mathbf{m})$ & $\mathbf{Q}_{\mathbf{h}}(\mathbf{k W})$ & $\mathbf{Q}_{\mathbf{l}}(\mathbf{k W})$ & $\mathbf{W}_{\mathbf{c}}(\mathbf{k W})$ & $\mathbf{C O P}$ \\
\hline 0,0762 & 4,049 & 2,538 & 1,039 & 3,897 \\
0,09 & 3,973 & 2,486 & 1,023 & 3,884 \\
0,1 & 3,93 & 2,457 & 1,015 & 3,872 \\
\hline
\end{tabular}

In Table 6 the impact of the distance between the pipes (ascending and descending) is presented. The results show that the interaction between the pipes is important; a small increase in the distance between the pipes improves the extraction.

Table 6

Parametric study: distance between pipe

\begin{tabular}{ccccc}
$\mathbf{D}_{\mathbf{c b}}(\mathbf{m})$ & $\mathbf{Q}_{\mathbf{h}}(\mathbf{k W})$ & $\mathbf{Q}_{\mathbf{1}}(\mathbf{k W})$ & $\mathbf{W}_{\mathbf{c}}(\mathbf{k W})$ & $\mathbf{C O P}$ \\
& & & & \\
\hline 0,01 & 3,82 & 2,379 & 0,998 & 3,828 \\
0,015 & 3,94 & 2,463 & 1,018 & 3,870 \\
0,02 & 4,049 & 2,538 & 1,039 & 3,897 \\
\hline
\end{tabular}

\section{Conclusion}

The Direct Expansion (DX) ground source heat pump is an interesting technology to increase the efficiency of building heating and cooling systems. A review of the literature reveals a dearth of scientific research on DX geothermal heat pump systems. Even though, models for standard heat pumps exist, no transient model of a DX ground source heat pump was found in the literature. To fill this gap and help proper design for this technology, a complete model coupling the heat pump and the ground heat exchanger was developed. This model was validated with a 24 -hour test in our laboratory where a maximum difference of $15 \%$ was observed. With the model, a 3-day test with an on/off cycle was performed to see the t ground response. Finally, a parametric study on the geothermal heat exchanger was presented. To conclude, the length of the borehole has the biggest impact on the capacity $\mathrm{Qh}$ of the system and a small impact on the COP. Also, to have the best heat extraction of the ground, the pipes shank 
spacing need to be important without increasing the borehole diameter. Further studies to evaluate the impact of other parameters will be conducted in the future.

\section{Acknowledgements}

Financial support for this study was provided by the Natural Sciences and Engineering Research Council of Canada (NSERC), École de technologie supérieure, and its financial partners; the authors would like gratefully to acknowledge their invaluable contributions. In addition, the valuable comments of the reviewers are gratefully acknowledged.

\section{References}

Austin, B.T., Sumathy, K., 2011, Parametric study on the performance of a direct-expansion geothermal heat pump using carbon dioxide. Applied Thermal Engineering 31, 3774-3782.

Beauchamp, B., Lamarche, L., Kajl, S., 2013, A Numerical Model of a U-Tube Vertical Ground Heat Exchanger Used as an Evaporator. Journal of Energy and Power Engineering 7, 237-249.

Beauchamp, B., Modélisation et validation expérimentale d'une pompe à chaleur géothermique à expansion directe, in, 2011.

Belzile, P., Lamarche, L., Rousse, D.R., 2016, Semi-analytical model for geothermal borefields with independent inlet conditions. Geothermics 60, 144-155.

Capozza, A., De Carli, M., Zarrella, A., 2012, Design of borehole heat exchangers for ground-source heat pumps: A literature review, methodology comparison and analysis on the penalty temperature. Energy and Buildings 55, 369379 .

Chen, J.C., 1966, Correlation for Boiling Heat Transfer to Saturated Fluids in Convective Flow. Industrial \& Engineering Chemistry Process Design and Development $5,322-329$.

Esen, H., Inalli, M., 2009, Modelling of a vertical ground coupled heat pump system by using artificial neural networks. Expert Systems with Applications 36, 10229-10238.

Eslami-Nejad, P., Ouzzane, M., Aidoun, Z., 2014, Modeling of a two-phase CO2-filled vertical borehole for geothermal heat pump applications. Applied Energy 114, 611-620.

Fannou, J.-L., Rousseau, C., Lamarche, L., Kajl, S., Modeling And Analysis Of A Direct Expansion Geothermal Heat Pump (Dx): Part II-Modeling Of Water-Refrigerant Exchanger, in: COMSOL Conference, Boston, 2012.

Fannou, J.-L.C., Rousseau, C., Lamarche, L., Stanislaw, K., 2014, Experimental analysis of a direct expansion geothermal heat pump in heating mode. Energy and Buildings 75, 290300.

Freund, E.A., Whitlow, G.S., 1959, Earth source heat pumps: characteristics, design, and operation. American Institute of Electrical Engineers -- Transactions -- Applications and Industry 77, 540-550.
Garimella, S., Christensen, R.N., 1995a, Heat Transfer and Pressure Drop Characteristics of Spirally Fluted Annuli: Part I-Hydrodynamics. Journal of Heat Transfer 117, 5460.

Garimella, S., Christensen, R.N., 1995b, Heat Transfer and Pressure Drop Characteristics of Spirally Fluted Annuli: Part II-Heat Transfer. Journal of Heat Transfer 117, 6168.

Geothemal heat pump manufacturing activites 2009, in: U.S.D.o. Energy (Ed.), Washington, D.C. 20585, 2010.

Gnielinski, V., 1975, New equations for heat and mass transfer in the turbulent flow in pipes and channels. Forschung im Ingenieurwesen $41,8$.

Goulburn, J.R., Fearon, J., 1978, Deep ground coil evaporators for heat pumps. Applied Energy 4, 293-313.

Goulburn, J.R., Fearon, J., 1983, DOMESTIC HEAT PUMP WITH DEEP HOLE GROUND SOURCE EVAPORATOR. Applied Energy 14, 99-113.

Halozan, H., 2011, Ground-Source Heat Pumps - Overcoming Market and Technical Barriers.

Hellström, G., 1991. Ground heat storage: thermal analyses of duct storage systems, Department of Mathematical Physics, Lund Univ.

Koyama, S., Miyara, A., Takamatsu, H., Fujii, T., 1990, Condensation heat transfer of binary refrigerant mixtures of R22 and R114 inside a horizontal tube with internal spiral grooves. International Journal of Refrigeration 13, 256-263.

Ndiaye, D., Bernier, M., 2010, Dynamic model of a hermetic reciprocating compressor in on-off cycling operation (Abbreviation: Compressor dynamic model). Applied Thermal Engineering 30, 792-799.

Rousseau, C., Comlan Fannou, J.-L., Lamarche, L., Ouzzane, M., Kajl, S., 2015, Modeling and experimental validation of a transient direct expansion geothermal heat exchanger. Geothermics 57, 95-103.

Ruiz-Calvo, F., Montagud, C., 2014, Reference data sets for validating GSHP system models and analyzing performance parameters based on a five-year operation period. Geothermics 51, 417-428.

Self, S.J., Reddy, B.V., Rosen, M.A., 2013, Geothermal heat pump systems: Status review and comparison with other heating options. Applied Energy 101, 341-348.

Smith, G.S., 1956, Intermittent ground grids for heat pumps. Heating, Piping and Air Conditioning 28, 127-133.

Underwood, C.P., 14 - Heat pump modelling A2 - Rees, Simon J, in: Advances in Ground-Source Heat Pump Systems, Woodhead Publishing, 2016, pp. 387-421.

Vargas, J.V.C., Parise, J.A.R., 1995, Simulation in transient regime of a heat pump with closed-loop and on-off control. International Journal of Refrigeration 18, 235-243.

Wang, H., Zhao, Q., Wu, J., Yang, B., Chen, Z., 2013, Experimental investigation on the operation performance of a direct expansion ground source heat pump system for space heating. Energy and Buildings 61, 349-355.

White, S.D., Yarrall, M.G., Cleland, D.J., Hedley, R.A., 2002, Modelling the performance of a transcritical CO2 heat pump for high temperature heating. International Journal of Refrigeration 25, 479-486.

Xiaotao, W., Chongfang, M., Yuanwei, L., 2009, An experimental study of a direct expansion ground-coupled heat pump system in heating mode. International Journal of Energy Research 33, 1367-1383. 